\title{
A Study on the Translation of "Sister" by Lu Yao under the Perspective of Translation Ethics
}

\author{
Xiaohui Zhang \\ Xi'an Fanyi University \\ Xi'an, China
}

\begin{abstract}
Under the new situation, the put forth of "the Belt and Road" and the implementation of "going out" strategy, give Shaanxi literature a vigorous vitality. In 2011, the writing of overseas literature promotion program compiled the English version "short film collection of Shaanxi writers". In the process of promoting these literary works, both the translation organization of the authorities, translators, the translation strategy and the publishers have an impact on the English version, the quality of the translation and the publishing scope while All of the these factors belong to the category of translation ethics research. Therefore, the author, guided by the theory of translation ethics, analyzes the current situation of Shaanxi literary works and guides the practice of translation. And the author takes the English version of "Sister" by Lu Yao as an example to analyze the translator's translation strategies in order to better grasp the market orientation and make the translation activities develop benignly.
\end{abstract}

Keywords-translation ethics; Shaanxi propaganda; the English version of "Sister"

\section{INTRODUCTION}

With the deepening of China's reform and opening up, General Secretary Xi Jinping proposed to layout focused on the implementation of the "four comprehensive" strategy and five development concept, and implied the decision and fresh practice "to catch up and excess to fulfill transformation and development". Shaanxi literature writers make a prominent "the belt and road" theme combined with its local characteristics and popularized greatly to implement "going out" strategy for literature. In five years, Shaanxi writers published more than a thousand literary monographs of all kinds, of which nearly a hundred articles won the award in the national, provincial literature awards activities. 13 of them were selected key support projects for Chinese Writing Association, and 34 works were included in the key literary and artistic support project by the Ministry of propaganda of the province Committee. The writers published168 poetry collections and more than 12,700 original poems in the publications at home and abroad. Among them, Jia Pingwa's novel "Qin cavity" won the seventh Mao Dun Literature Award, and Gao Jianqun's novels "Great Plains" as well as Hong Ke's novels "Wuerhe" and "Life Tree" were nominated for the seventh and the eighth Mao Dun Literary Award; Wu

Project name: College project of Xi'an Fanyi University: A Study on the Translation of "Sister" by Lu Yao under the Perspective of Translation Ethics Project No.: 17B12.
Kejing's novella "the blue flower on handcuffs" won the fifth Lu Xun Literature Award. There was a new round of creative writings wave in Shaanxi, which greatly enhances the brand influence of Shaanxi literary writers. At the same time, the writers implemented Shaanxi literature overseas translation referral plan (shorted for SLOT plan) and compiled and published a large-scale commemorative collection of sinorussian "love of Russia", the English version of "Short story collection of Shaanxi writers". This is the first collectively translated works of provincial Writers in China. In addition, Ye Guangqin's English version "Qing mu chuan" has been published. Du Wenjuan's "Ali Ali" was published in 2013 in English. With the increasing international status of Xi'an and the support policies of our nation, we can expect there will be more Shaanxi novels being promoted overseas in the future.

However, In the process of translation and publication of these literary works, the organization of the government, the translators, the translator's professional accomplishment, the publisher and the sponsors, etc. will affect the text quality and even the scope of the translation works. Using the correct theory to guide the translation activities become the subject researched by translation scholars.

\section{THE THEORY OF TRANSLATION ETHICS AND ITS SIGNIFICANCE IN SHAANXI LITERATURE}

From ancient times, China is a country with rich ethical thinking. In different periods of translation history, translators proposed different translation standards such as the Principles of "Goodness" and "Faithfulness" in "The preface of Dhammapada". "Goodness" refers to the translation must be faithful to the original text, the translator's responsibility and the translators' faith of Buddhism; "Faithfulness" refers to the faith to the original text and the readers. In the "Dialectics", the translators come up with morality theory, that is, the translator's sense of mission. This thought has been fully reflected in later works of modern translators such as Yan Fu and Lin Shu. At the same time, they put forward the translation theory of "Yiqun" and "save the nation" and "educated" the people by introducing Western advanced works into our country, and inspired people's thought and the translation thought of "utilitarian".

In the West, in addition to the common law of "goodness" and "faithfulness", the principle of faithfulness to the readers of the translation attracts great attentions whether it is Chinese translation of Buddhist scripture or the translation of the Bible 
in the West. In the process of translation, the western people also put forth the norm for translators and the translation principle to enrich the target language.

With the gradual deepening of China's reform and opening up, the economic development of eastern region tends to saturation so the national policy tilts to western areas. The statuses of Shaanxi as the leading province of western China and Xi'an as the focus of the development of the western city have been highlighted with the proposals of "the belt and road" and "the Chinese dream". In order to promote and enhance the economic and cultural soft power of Shaanxi, the government promotes Shaanxi tourism and literary works. Shaanxi literature industry was greatly popularized and the government implements literature "going out" strategy. They not only support key literary and artistic creation projects in the country, but also conduct SLOT plan. The writers compiled and published a large-scale commemorative collection of sinorussian "love of Russia", the English version of "Short story collection of Shaanxi writers", "Qing mu chuan" and "Ali Ali", which greatly boost Shaanxi literature.

However, we should also be clear about Shaanxi novel development deficiencies. First, Shaanxi lack of packaging teams for writers and works. The ideas of Shaanxi writers are relatively conservative, and "going out" consciousness is relatively weak, which causes many writers only focus on their own qualities, while ignoring the publication and distribution, works popularization as well as their great influence. There is still a big gap between Shaanxi and coastal developed areas. Second, there are many dialects in Shaanxi novels, resulting in the difficulty of translation. For example, when the movie "White Deer" broadcasts, the title was translated as White Deer Plain. As local Shaanxi people, they know that the title itself is a profound connotation: First, in Shaanxi native, they called hills higher than the ground for mound, and it is truly different from real hill. The upper part of the hill is sharp while the mound is flat above and people can live there or plant crops. However, the word plain in English does not have this special meaning. Moreover, Bai and $\mathrm{Lu}$ in the name of the novel on behalf of two families who originally live in the mound, they lived from late Qing Dynasty to the new China. The history changes while the resentment and disputes between two families don't stop. Thus, let alone the details of the translation of the internal chapters of the novel, even a name in this novel needs to be carefully considered. Thirdly, the theme of Shaanxi novels is much related to the fate of Chinese peasants and it is a discussion of Chinese local literature. With China's three decades reform and opening up, that kind of hard life has become the memory of a generation, which has grown up the gap between the newly grown-up readers, so they can hardly find a resonance from the works. The reduction of the reader determines whether the novel needs to be translated or published.

Translation ethics is ethical normative research on translation activities, translation theory, translation criticism and translation teaching. That is, to examine all aspects of translation from the perspective of ethics. Therefore, the translation ethics mainly includes "translator ethics", "middleman ethics" and "reader ethics" and the acceptance and dissemination of the translation. Taking the theory of translation ethics as the guideline, the author analyzes Shaanxi translators, whether the translators follow the translator's ethics, that is, the motivations of the translators and the purpose of the translation, whether the translation is faithful to the original text, and translation methods and strategies adopted by translators; Middlemen are the organizers of translation activities and the influence on the translation and the scope of publication. The above deeply affects the quality and influence power of Shaanxi's novel "going out" strategy. Therefore, the translation ethics has the strategic significance to the translation and promotion of Shaanxi novels.

\section{The TRANSLAtion OF "SiSTER" By LU TAO UNDER THE PERSPECTIVE OF TRANSLATION ETHICS}

"Sister" is a short story written by Lu Yao in 1981. The year 1981 was at the time of smashing four gangs and two years after the resumption of college entrance examination. At that time, there are many educated youth who are persecuted by the gang go to hometown to experience life, they only have two ways to change their situations: to return to the city or to participate in the 1979 college entrance examination. The great living environment setbacks brought the changes of consciousness and life, which provided literary conditions for "sister". Its English version appeared in Short story collection of Shaanxi writers in 2011. Short story collection of Shaanxi writers was one part of SLOT plan, which was translated and organized by Shaanxi Provincial Writers Association and the Shaanxi Provincial Translation Association. The author takes translation ethics theory as a guide to analyze the English version of "sister" to find whether it follows the principle.

\section{A. The Motivation of Translators and Selection of Text}

This short story "Sister" by Lu Yao is included in the English version of Short story collection of Shaanxi writers. The publication of this novel is sponsored by the SLOT plan and translated by the Shaanxi Provincial Writers Association and the Shaanxi Provincial Translation Association. Although it was organized by the above two units, the selection of text was determined by the translator. The reasons why the translator chooses "sister" as the original text are as follows: First, as the representative writer of Shaanxi local literary fiction writing, Lu Yao has greater influence in Chinese domestic literature than other ordinary writers and his works are more representative attract more attention of reader. Second, "sister" describes the era of China transition period from the end of the Cultural Revolution to reform and opening up, during this period, the educated youth return to the city, which brought social problems with society universal meaning. Third, the translator's own age is not much different from that stage described in "sister", so some of the ideas in the original text are coincided with the translator himself to some extent.

\section{B. Ethics Related to Author}

First of all, the translator of "sister" is the graduate tutor Professor Zhang Min who works in School of Foreign studies in Xi'an Jiaotong University. He has translated the novels Jude the Obscure and The Police \& Sting. Zhang Min graduated from South China Normal University in 1988 with a bachelor's degree in English Language and Literature. $\mathrm{He}$ is 
knowledgeable in English language and his major is translation theory and practice, so he has rich experience in translation. Moreover, the translator's own age is similar to and the background times of "sister", so he can help the translator to understand the original expression of the text to a large extent. After the completion of undergraduate studies, Professor Zhang Min was admitted to the Lanzhou University as a graduate student and majored in British and American literary translation. After graduating in 1991, he has been working in Xi'an Jiaotong University. For nearly three decades in Xi'an, he has been influenced by the language environment expressed in the Shaanxi dialect, and he has a profound understanding of the dialect in the novel. At the same time, his major has made him understanding deeply in Anglo-American literature. What's more, the translator himself translated constantly besides teaching, so he is greatly familiar to the novel's genre and subject. All of these created a favorable prerequisite for the English translation of the "sister". Let's see the examples of the English translation:

1. The lad loved by Sister is Gao Limin, an educated youth (urban high school graduates who went to work and settle in the rural areas in response to the call of Man Zedong during the Cultural Revolution) from the provincial capital.

Analysis: Educated youth is a kind of model under the call of Mao Zedong in the 1960s. It refers to the urban youth who go to mountain areas and rural areas to experience countryside life. The translator clearly understood the activity at the time and understood the background of the novel. The translation was made by annotation, which not only retains the structure of the original text, but also helps the target language reader understand the social background of the novel.

2. Those years found him a most wretched dog, for being the son of spies was worse than being reactionaries in the eyes of the masses.

Analysis: wretched $\operatorname{dog}$ is a kind of slang in Shaanxi dialects, means merciful. The translator understood it correctly and translates it in an authentic expression, which is highly consistent with style and Shaanxi dialect.

3. When all these preparations were finished, she gives me 2 yuan and tells me to buy 2 jin of mutton in the town.

Analysis: Finished, is also Shaanxi dialect, means that things are over. The translation expresses clearly, that is, the sister prepared all the other materials for dumplings and then asked me to buy some meat.

4. Besides, a long-term view shows that our marriage involves not only the problem of separation, but the practical disparities between job and occupation, commodity grain and rural grain. (Commodity grain and rural grain: symbol of status; commodity grain stands for urban residence while rural grain rural residence.)

Analysis: Commodity grain and rural grain are an alias that distinguishes differences between urban and rural household. At that time, China's census register management system is very strict because the country gives support to urban household in pension and medical treatment other than rural households, so it is a symbol of life security. Translator's understanding to the original text is aptly and outright.

All in all, whether in grasp of the original genre and style or in the understanding of the original text and translation strategy, the translator can do it appropriately and properly, and basically restored the expression of the original ideas.

\section{Middlemen Ethics}

The internal control factor for translation is the translator and external control factors are patrons and patrons can be individuals, groups, religions, groups, political parties, social class, publishers, media, etc., that is, persons or groups that affect translation or control translation activities. These intermediaries are not directly involved in the translation. "Sister" was collected in the stories set by Shaanxi Provincial Writers Association and the Shaanxi Provincial Translation Association, so which writers were chosen to translate the works is determined by the two organizations. At the same time, the organizers also invited overseas publishing experts to select their works and follow recommendations and opinions of experts such as Robert Farnsworth, Mary Warpeha. They judge the taste of foreign readers and reading tendencies from the perspective of overseas literature market to draw a strong pen for the success of Shaanxi novel "going out" strategy.

\section{THE INFLUENCE ON THE POPULARIZATION OF THE ENGLISH VERSION SHAANXI NOVELS}

From the above analysis of the English translation "sister", we can conclude that there is a long way for Shaanxi novel to "going out". First, it needs more local translators and translation researchers to attend this activity and popularize more Shaanxi readers abroad to expand the influence of Shaanxi literature; Second, Shaanxi writers themselves should also be actively involved in the promotion of their own activities, pay more attention to overseas translation market to expand current foreign sources; Third, the development of the times calls for the new "local literature", it is no longer poor life described by writers like Lu Yao and Jia Pingwa, but a better village life after the reform and opening up.

\section{CONCLUSION}

Finally, the successful publication of "sister" and a number of translations of Shaanxi novels pointed out the direction for the future development of Shaanxi novels. With the change of the Shaanxi government strategy, the enthusiasm of the literary circles in Shaanxi Province has been continuously improved, and it is believed that the Shaanxi Provincial Writers Association and the Shaanxi provincial Translation Association will intensify their cooperation and introduce more English translations of Shaanxi writers.

\section{REFERENCES}

[1] Old Land New Tales: 20 Best Stories of Shaanxi Writers. [M].Beijing: China Intercontinental Press, 2011

[2] Peng Ping. Translation Ethics [M]. Beijing: Central Compilation \& Translation Press, 2013 
[3] Bai Jie. A Study on the English Version of " Big Breasts \& Wide Hips " under Chesterman's Translation Ethics Model [D]. China excellent master's degree thesis database, 2015

[4] Wu Jie. A Study of Literary Language in "Ordinary World" [D]. China excellent master's degree thesis database, 2013 